\title{
Availability and Transformations of Phosphorus in Calcareous Sandy Soil as Affected by Farmyard Manure and Elemental Sulfur Applications
}

Abu El-Eyuoon Abu Zied Amin ${ }^{1}$

\begin{abstract}
An incubation experiment was conducted to study the effects of farmyard manure (FYM) and elemental sulfur (S) on availability, fractionation and transformation of phosphorus in calcareous sandy soil. Soil samples were treated with FYM at levels: $0\left(\right.$ FYM $\left._{0}\right), 2.5\left(\right.$ FYM $\left._{1}\right), 5$ $\left(\mathrm{FYM}_{2}\right)$ and $7.5\left(\mathrm{FYM}_{3}\right) \mathrm{g} \mathrm{pot}^{-1}$ and $\mathrm{S}$ at levels: $0\left(\mathrm{~S}_{0}\right), 0.1$ $\left(S_{1}\right), 0.2\left(S_{2}\right)$ and $0.3\left(S_{3}\right) g_{\text {pot }^{-1}}$. The soil was incubated for ten weeks under field capacity conditions. Additions of FYM caused significant increases in the amount of available $P$ (Olsen-P) from 34.57 to $44.54 \mathrm{mg} \mathrm{kg}^{-1}$. The $S$ with FYM application significantly increased Olsen-P of this soil at $S_{1} F Y M_{1}$ from 42.95 to $52.70 \mathrm{mg} \mathrm{kg}^{-1}$. Significant reduction in Olsen-P was observed at $S_{2}$ and $S_{3}$ levels, but the addition of $S$ at $S_{1}$ level led to its insignificant increase. FYM application transformed $\mathrm{HCl}$ $\mathrm{Pi}, \mathrm{NaOH}$ II-Pi and residual $\mathrm{P}$ to $\mathrm{NH}_{4} \mathrm{Cl}-\mathrm{P}, \mathrm{NaHCO}_{3}-\mathrm{Pi}$, $\mathrm{NaHCO}_{3}-\mathrm{Po}, \mathrm{NaOH}$ I-Pi, NaOH I-Po and $\mathrm{NaOH}$ II-Po fractions. Application of $\mathrm{S}$ converted the $\mathrm{NH}_{4} \mathrm{Cl}-\mathrm{P}, \mathrm{NaOH}$ I-Pi and $\mathrm{HCl}-\mathrm{Pi}$ fractions to $\mathrm{NaHCO}_{3}-\mathrm{Pi}, \mathrm{NaHCO}_{3}-\mathrm{Po}$, $\mathrm{NaOH}$ I-Po, NaOH II-Pi, NaOH II-Po and residual $\mathrm{P}$ fractions. It's recommended adding FYM to calcareous sandy soils as well as adding $S$ combined with FYM to improve the soil properties.
\end{abstract}

Keywords: Incubation; Labile-P; Olsen-P; Phosphorus fractions

\section{INTRODUCTION}

Calcareous sandy soils are common in many areas around the world specially arid and semiarid regions, that suffer from scarcity of most nutrients availability particularly phosphorus. Many soils in their natural state do not contain adequate amount of available P to maximize crop yield (Hopkins and Ellsworth, 2005). Phosphorus availability in soils is affected by several factors such as soil reaction, organic matter, texture (Verma, 2013), calcium carbonate (Hopkins and Ellsworth 2005), parent material, weathering and climatic conditions (Fuentes et al. 2008). Moreover, phosphorus availability in calcareous soils is influenced by many factors as size and amount of free $\mathrm{CaCO}_{3}$, activity of $\mathrm{Ca}^{+2}$ ions as well as amount of clay (Sims and Ellis, 1983; Tisdale et al., 1997). In calcareous soils, interaction of soluble phosphate from adding mineral phosphate fertilizers and soil $\mathrm{Ca}$ ions occurs and produces dicalcium phosphate which with time

\footnotetext{
${ }^{1}$ Assiut University, Soils and Water Department,

Faculty of Agriculture, Assiut, Egypt, P.O. Box: 71526,

e-mail: abueleyuoon.amin@aun.edu.eg, abueleyuoon@gmail.com,

tel: 00201143784083

Received February 26, 2018, Accepted March 27, 2018
}

transforms to tricalcium phosphate as well as phosphorus adsorbed on calcite surfaces, leading to decrease in solubility and availability of soil phosphorus (Brady and Weil, 1999; Delgado and Torrent, 2000; Leytem and Mikkelsen, 2005). Amelioration of $\mathrm{P}$ availability and uptake by plants is important for economic, humanitarian and environmental reasons (Vance et al., 2003). The suitability extent of calcareous soils for agriculture depends on management systems via adding of organic materials and some amendments to improve availability of nutrients, particularly phosphorus (Al-Oud, 2011; Karimi et al., 2012). Applied municipal compost to some calcareous soils was reported to increase soil phosphorus availability (Hosseinpur et al., 2012). Organic manure additions also caused an increment in Olsen extractable P of soil (Bahl and Toor, 2002). In P-fixing soils, applications of organic matter were reported to increase available $\mathrm{P}$ because of mineralization (Iyamuremye and Dick, 1996). The oxidation of sulfur in the calcareous soils is influenced by many factors like particle size of sulfur, soil moisture, temperature, $\mathrm{pH}$, nutrient status and microbial activity of the soils as well as the oxidation of sulfur is rapid under low soil $\mathrm{pH}$ conditions (Havlin et al., 1999). Oxidation of sulfur in the soil is achieved by certain groups of some microorganisms as acidophilic bacteria, especially Thiobacillus spp. (Seidel et al., 1998; Kayser et al., 2000). Elemental sulfur additions to calcareous soil caused decrease soil $\mathrm{pH}$ and increase in Olsen extractable phosphorous (Modaihsh et al., 1989). Phosphorus fractions were categorized into three groups are labile $\mathrm{P}$ includes $\mathrm{NH}_{4}-\mathrm{Cl}$ and $\mathrm{NaHCO}_{3}-\mathrm{P}$ ( $\mathrm{Pi}$ and $\mathrm{Po}$ ); moderately labile $\mathrm{P}$ contains $\mathrm{NaOH}-\mathrm{P}$ ( $\mathrm{Pi}$ and $\mathrm{Po}$ ) and $\mathrm{HCl}-\mathrm{Pi}$; stable $\mathrm{P}$ or non labile was $(\mathrm{NaOH}$ II-Pi, $\mathrm{NaOH}$ II-Po and residual $\mathrm{P}$ ) according to (Niederberger et al., 2015). Phosphorus fractions may vary in mobility, bioavailability and chemical behavior and can be transformed under certain conditions (Jalali and Ranjbar, 2010). Generally, manure application has important dynamic effects on chemical fractions of phosphorus because $\mathrm{P}$ released from manure is gradually converted into available forms by the time (Halajnia et al., 2009). It is well known that the addition of phosphate fertilizers to calcareous soils happen phosphorus may turn into insoluble forms which are 
unavailable to plants. So, the objectives of the current study were to assess the effects of adding farmyard manure, elemental sulfur or both to calcareous sandy soil on (1) soil $\mathrm{pH}$, (2) phosphorus availability, (3) changes of phosphorus fractions, and (4) transformations of phosphorus forms from non-labile $\mathrm{P}$ (stable P) to labile P.

\section{MATERIALS AND METHODS}

Incubation experiment: An incubation experiment was conducted, during January 2014, to study the effects of farmyard manure (FYM) and elemental sulfur (S) as well as inoculation with Thiobacillus bacteria on the availability and transformations of phosphorus in calcareous sandy soil. Soil sample at 0-30 cm depth was collected from El-Ghorieb Experimental Station Farm, Assiut University, Assiut, Egypt. This soil was classified according to U.S. Soil Taxonomy as Entisols; Typic Torripsamments.. Table 1 shows some physical and chemical properties of this soil and farmyard manure. The collected soil samples were air dried, crushed, and passed through $2 \mathrm{~mm}$ sieve. Plastic pots $(7.5 \mathrm{~cm}$ in height and $10.5 \mathrm{~cm}$ in diameter at the top and $8.7 \mathrm{~cm}$ at the base) containing $500 \mathrm{~g}$ calcareous sandy soil were used in this experiment. Superphosphate fertilizer $\left(15.5 \% \mathrm{P}_{2} \mathrm{O}_{5}\right)$ at level $0.15 \mathrm{~g}$ was added to each pot (equivalent to $720 \mathrm{~kg} \mathrm{ha}^{-1}$ ). Farmyard manure (FYM) was air-dried, crushed, and passed through 2 $\mathrm{mm}$ sieve. Then, it was added and mixed with soil in each pot at level of $0\left(\mathrm{FYM}_{0}\right), 2.5\left(\mathrm{FYM}_{1}\right), 5\left(\mathrm{FYM}_{2}\right)$ and $7.5\left(\mathrm{FYM}_{3}\right) \mathrm{g} \mathrm{pot}^{-1}$ (equivalent to $0,12,24$ and 36 ton $\left.\mathrm{ha}^{-1}\right)$. At that time, elemental sulfur (S) was added to the soil in each pot at levels of $0\left(\mathrm{~S}_{0}\right), 0.1\left(\mathrm{~S}_{1}\right), 0.2\left(\mathrm{~S}_{2}\right)$ and $0.3\left(\mathrm{~S}_{3}\right) \mathrm{g} \mathrm{pot}^{-1}$ (equivalent to $0,480,960$ and 1440 $\left.\mathrm{kg} \mathrm{ha}^{-1}\right)$ as fine granules and mixed with soil that was

Table 1. Physico-chemical properties of the experimental soil and farmyard manure

\begin{tabular}{|c|c|}
\hline Property & Value \\
\hline \multicolumn{2}{|c|}{ Soil } \\
\hline \multicolumn{2}{|c|}{ Particle size Distribution } \\
\hline Clay $(\%)$ & 6.8 \\
\hline Silt $(\%)$ & 6.4 \\
\hline Sand $(\%)$ & 86.8 \\
\hline Texture & Loamy sand \\
\hline Field capacity (\% w/w) & 10.77 \\
\hline Organic carbon $\left(\mathrm{g} \mathrm{kg}^{-1}\right)$ & 6.9 \\
\hline $\mathrm{CaCO}_{3}\left(\mathrm{~g} \mathrm{~kg}^{-1}\right)$ & 249.5 \\
\hline $\mathrm{pH}(1: 1)$ & 7.55 \\
\hline Available $\mathrm{P}\left(\mathrm{mg} \mathrm{kg}^{-1}\right)$ & 24.32 \\
\hline \multicolumn{2}{|c|}{ Farmyard manure } \\
\hline Organic carbon $\left(\mathrm{g} \mathrm{kg}^{-1}\right)$ & 134.5 \\
\hline $\mathrm{pH}(1: 1)$ & 8.52 \\
\hline Total P $\left(\mathrm{mg} \mathrm{kg}^{-1}\right)$ & 1202.99 \\
\hline
\end{tabular}

inoculated with Thiobacillus bacteria which was added to the pots in liquid form. Experimental design was randomized complete block with factorial arrangement of treatments with three replications. Each pot was left at the same place during period of incubation in the laboratory at room temperature for ten weeks with keeping moisture content at field capacity. After incubation, soil sample was taken from each pot and airdried, crushed, passed through $2 \mathrm{~mm}$ sieve and kept for analysis.

Chemical analysis: Available phosphorus in soil samples was extracted using $0.5 \mathrm{M} \mathrm{NaHCO}_{3}$ of $\mathrm{pH} 8.5$ fractionation of soil samples was performed according to the methods described by Hedley et al. (1982) and modified by Chen et al. (2000) as shown in Fig. 1. In these methods, $1 \mathrm{~g}$ soil was subjected to sequential fractionation. The phosphorus in $\mathrm{NaHCO}_{3}$ and $\mathrm{NaOH}$ supernatants were digested by potassium persulfate in order to determine its total content of $\mathrm{P}(\mathrm{Pi}+\mathrm{Po})$, a calculation of Po was then made as described by Bowman (1989). Residual $P$ was calculated as difference between total $\mathrm{P}$ and sum of different fractions (Frossard et al., 1989). Phosphorus in the extracts was measured colormetrically by chlorostannous phosphomolybdic acid method in sulphuric acid system (Jackson, 1973).

Statistical analysis: Data were analyzed by standard ANOVA procedure and significance was always based on $P \leq 0.05$ level using Duncan's Multiple Range Test. Statistical analysis in this experiment was done by using MSTAT program according to Steel and Torrie (1982). according to Olsen et al. (1954). Phosphorus sequential 


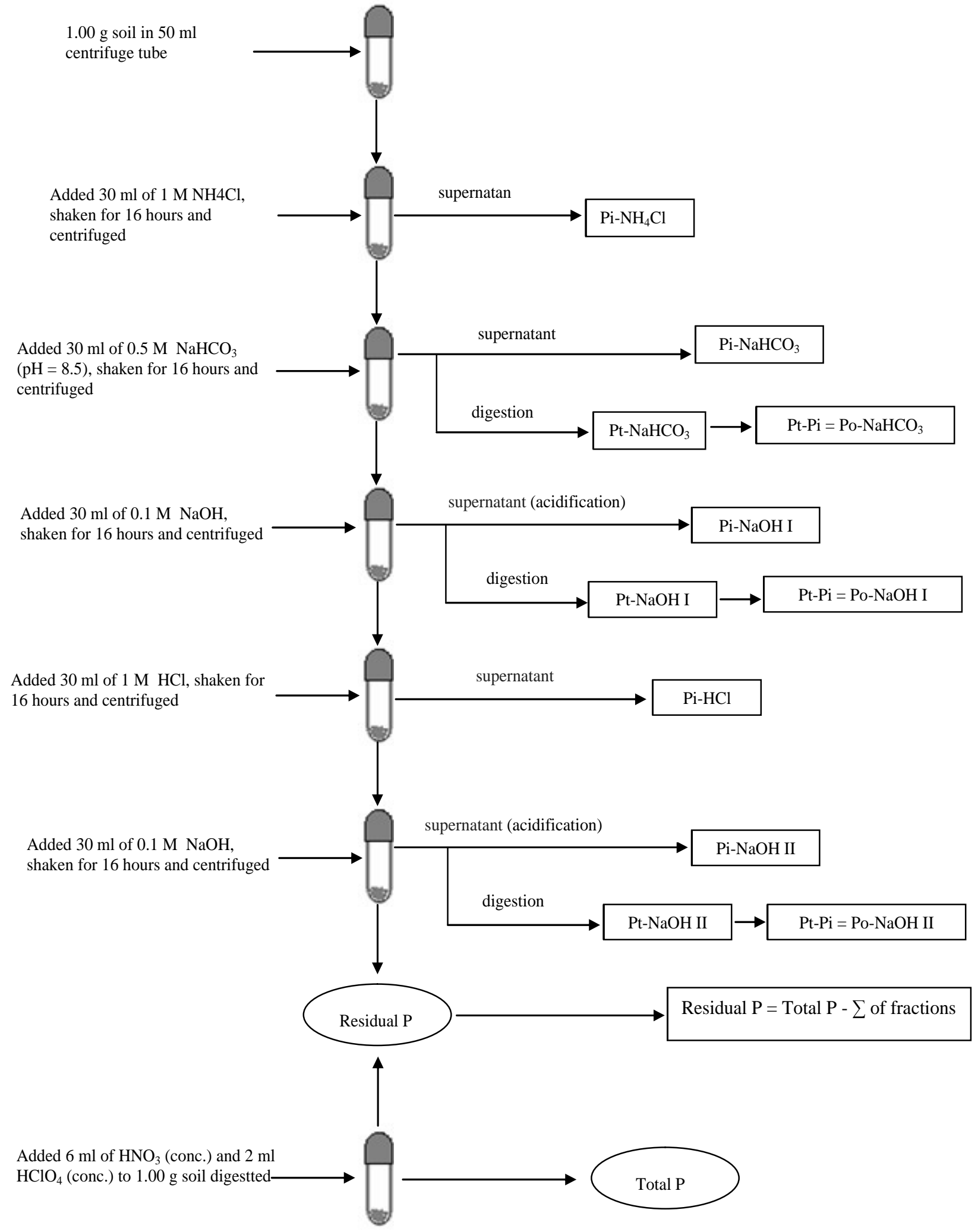

Figure 1. Sequential fractionation of soil phosphorus according to Hedley et al. (1982) modificated by Chen et al. (2000) 


\section{RESULTS AND DISCUSSION}

\section{Farmyard manure application}

Available and total phosphorus: Incubating farmyard manure with calcareous sandy soil for ten weeks resulted in significant increases $(P \leq 0.05)$ of available phosphorus in soil from $34.57 \mathrm{mg} \mathrm{kg}{ }^{-1}$ of $\left(\mathrm{FYM}_{0}\right)$ to $44.54 \mathrm{mg} \mathrm{kg}^{-1}$ with adding the highest level of farmyard manure (Table 2). Farmyard manure addition to calcareous sandy soil led to a significant increase in total soil phosphorus compared to $\mathrm{FYM}_{0}$ treatment (Table 2). Treating this soil with FYM increased total $\mathrm{P}$ from $440.97 \mathrm{mg} \mathrm{kg}^{-1}\left(\mathrm{FYM}_{0}\right)$ to $479.39 \mathrm{mg} \mathrm{kg}^{-1}$ at the highest level of farmyard manure $\left(\mathrm{FYM}_{3}\right)$. From the results of this study, we conclude that the available phosphorus after an incubation period increased in calcareous sandy soil by using farmyard manure fertilization. The application of farmyard manure to the calcareous sandy soil at high level caused relative increases in the available phosphorus by $28.8 \%$ compared to the control. Phosphorus availability in soil increased when phosphorus released from organic matter during the mineralization process (Iyamuremye and Dick, 1996; Verma et al., 2005). The available phosphorus in calcareous sandy soil at Assiut governorate, Egypt, which treated with farmyard manure significantly improved, the addition of FYM to this soil raised the available $\mathrm{P}$ from 11.91 to $16.68 \mathrm{mg}$ $\mathrm{kg}^{-1}$ (Badawy et al., 2011). Al-Oud (2011) indicated that the availability of phosphorus was significantly increased from 4.65 to $33.72 \mathrm{mg} \mathrm{kg}^{-1}$ at treating rock phosphate in calcareous soil in Saudi Arabia by different rates of organic manure. The total $\mathrm{P}$ increased with fertilization of the calcareous sandy soil by FYM. Applying FYM at highest level to the calcareous sandy soil added about $38.42 \mathrm{mg} \mathrm{kg}^{-1}$ of phosphorus for the total phosphorus in the control treatment. The organic matter is considered a source of nutrients; it is expected to add phosphorus to soil and increase total content of phosphorus. Manure application increased total soil phosphorus (Qian and Schoenau, 2000).

\section{Phosphorus fractions}

Labile fractions: The results showed a significant increase in phosphorus extracted by $\mathrm{NH}_{4} \mathrm{Cl}\left(\mathrm{NH}_{4} \mathrm{Cl}-\mathrm{P}\right)$ with adding farmyard manure to calcareous sandy soil (Table 2). Farmyard manure application to calcareous sandy soil raised $\mathrm{NH}_{4} \mathrm{Cl}-\mathrm{P}$ from $29.00 \mathrm{mg} \mathrm{kg}^{-1}$ at $\mathrm{FYM}_{0}$ to $39.81 \mathrm{mg} \mathrm{kg}^{-1}$ at $\mathrm{FYM}_{3}$. Incubation of FYM with calcareous sandy soil led to significant increment in $\mathrm{NaHCO}_{3}-\mathrm{Pi}$ and $\mathrm{NaHCO}_{3}-\mathrm{Po}$ fractions (Table 2). This enhanced soil inorganic Phosphorus fraction extracted by $\mathrm{NaHCO}_{3}$ which ranged from 72.14 to $88.42 \mathrm{mg} \mathrm{kg}^{-1}$ with increasing farmyard manure supply. Moreover, application of FYM to calcareous sandy soil resulted in an increase in $\mathrm{NaHCO}_{3}$-Po from 54.16 to $80.33 \mathrm{mg} \mathrm{kg}^{-1}$ with increasing farmyard manure supply. The response of easily available $\mathrm{NH}_{4} \mathrm{Cl}-\mathrm{P}$ was noticed at $\mathrm{FYM}$ applications. The highest concentration of $\mathrm{NH}_{4} \mathrm{Cl}-\mathrm{P}$ was observed in $\mathrm{FYM}_{3}$ treatment. $\mathrm{NH}_{4} \mathrm{Cl}-\mathrm{P}$ accounted about $6.6 \%$ of total $\mathrm{P}$ for control and $8.3 \%$ at the highest level of FYM in the soil after 10 weeks incubation. The additions of sewage sludge and chicken litter to the soil increased the $\mathrm{NH}_{4} \mathrm{Cl}$ extracted phosphorous (Kalembasa and Kuziemska, 2007). The $\mathrm{NaHCO}_{3}-\mathrm{Pi}$ and $\mathrm{NaHCO}_{3}-$ Po fractions reacted strongly and rapidly to FYM applications because the addition of phosphorus via fertilization by FYM. The concentration of $\mathrm{NaHCO}_{3}-\mathrm{Pi}$ and $\mathrm{NaHCO}_{3}$-Po fractions in this soil gradually increases with increasing FYM levels and the highest concentrations of $\mathrm{NaHCO}_{3}-\mathrm{Pi}$ and $\mathrm{NaHCO}_{3}-\mathrm{Po}$ fractions were found at the highest level of fertilization by FYM. Several studies found that the additions of organic amendments such as compost (Scherer and Sharma, 2002) and manure (Qian and Schoenau, 2000) to the soil increased the $\mathrm{NaHCO}_{3}$-Pi fraction. Poultry manure was applied combination with superphosphate led to increasing organic $\mathrm{P}$ after 4 weeks, but decrease at 6 weeks when poultry manure was applied alone (Ojo et al., 2014).

Moderately labile fractions: $\mathrm{NaOH}$ I-Pi fraction significantly increased with FYM additions to calcareous sandy soil at $\mathrm{FYM}_{1}$ level. FYM application to calcareous sandy soil resulted in an increasing $\mathrm{NaOH}-\mathrm{Pi}$ from 17.36 to $20.68 \mathrm{mg} \mathrm{kg}^{-1}$ with using $\mathrm{FYM}_{1}$ level. NaOH I-Po fraction significantly increased with the FYM addition to calcareous sandy soil (Table 2). Increase in $\mathrm{NaOH}$ I-Po of this soil due to FYM was from 19.22 at control treatment to $33.28 \mathrm{mg} \mathrm{kg}^{-1}$ at the highest level of farmyard manure. Incubation with farmyard manure along with calcareous sandy soil led to decline in HCl-Pi from 159.50 to $153.16 \mathrm{mg} \mathrm{kg}^{-1}$ with using $\mathrm{FYM}_{3}$ treatment (Table 2). Addition of steer manure and alfalfa residues to soils also showed increases of $\mathrm{NaOH}$ I-Pi fraction (Iyamuremye et al., 1996). The concentration of labile Po in the soil was reported to increase with the application of manure (Yin and Liang, 2013). Addition of liquid swine manure to soil was found to raise $\mathrm{NaOH}$ I-Po fraction after 16 weeks of incubation (Qian and Schoenau, 2000). The moderately labile Po fraction increment with fertilized the soil by manure (Yin and Liang, 2013). In spite of the applied FYM was non-significant on HCl-P fraction, the HCl-P fraction accounted for a higher percentage of the total $\mathrm{P}$ (36.2 to $31.9 \%)$ than all fractions. The soil fertilized with FYM the percentages of $\mathrm{HCl}-\mathrm{P}$ fraction reduced from 36.2 to $31.9 \%$. The 
results showed that in soil under study the major proportion of $\mathrm{P}$ was associated with $\mathrm{Ca}$. Liquid swine manure additions to soil non significantly decreased HCl-Pi fraction after 16 weeks of incubation (Qian and Schoenau, 2000). Steer manure application or lime to some soils caused no significant changes in $\mathrm{HCl}-\mathrm{Pi}$ fraction (Iyamuremye et al., 1996). However, Sui et al. (1999) found reduction in HCl-Pi fraction with adding biosolids to soil. On the other hand, some researchers found that addition of manure to soil raised phosphorus concentrations associated with calcium (Yin and Liang, 2013).

Stable fractions: Farmyard manure application to this soil increased $\mathrm{NaOH}$ II-Po fraction (Table 2). The addition of farmyard manure to this soil resulted in increasing $\mathrm{NaOH}$ II-Po fraction from $2.46 \mathrm{mg} \mathrm{kg}^{-1}$ $\left(\mathrm{FYM}_{0}\right)$ to $4.37 \mathrm{mg} \mathrm{kg}^{-1}$ at $\left(\mathrm{FYM}_{2}\right)$. NaOH II-Po fraction increases slightly because FYM applied. The highest concentration $\mathrm{NaOH}$ II-Po observed in $\mathrm{FYM}_{2}$ treatment. The phosphorus was less abundant $\mathrm{P}$ fraction of this soil and constituting between $0.9 \%$ and $1.3 \%$ of the total P. The results obtained from this experiment also showed a significant decrease in residual $\mathrm{P}$ fraction with FYM as compared to control treatment (Table 2). The addition of farmyard manure at level $\mathrm{FYM}_{3}$ to this soil led to a reduction in residual $\mathrm{P}$ from 70.46 to 47.73 $\mathrm{mg} \mathrm{kg}^{-1}$. Reduced amounts of residual $\mathrm{P}$ fraction due to FYM additions to this soil may be transformed to other $\mathrm{P}$ fractions, especially $\mathrm{NaHCO}_{3}-\mathrm{Pi}$ and $\mathrm{NH}_{4} \mathrm{Cl}-\mathrm{P}$. Generally, the concentration of $\mathrm{P}$ in residual fraction tended to decrease with treating calcareous sandy soil by FYM under incubation, indicating former fractions served as a primary sink for $\mathrm{P}$ added to the soil. In soil treated with FYM at $\mathrm{FYM}_{3}$ there were reductions of

Table 2. Mean effects of farmyard manure addition on the amount of available, fractions and total phosphorous in calcareous sandy soil (values are averages of three replications)

\begin{tabular}{|c|c|c|c|c|c|}
\hline & \multicolumn{4}{|c|}{ Treatment $^{*}$} \\
\hline & & FYM $_{0}$ & FYM $_{1}$ & $\mathrm{FYM}_{2}$ & $\mathrm{FYM}_{3}$ \\
\hline \multicolumn{2}{|c|}{ Olsen-P $\left(\mathrm{mg} \mathrm{kg}^{-1}\right)$} & $34.57 \mathrm{C}$ & $39.99 \mathrm{~B}$ & $41.41 \mathrm{~B}$ & $44.54 \mathrm{~A}$ \\
\hline \multirow{7}{*}{ 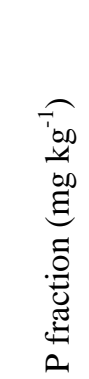 } & $\mathrm{NH}_{4} \mathrm{Cl}-\mathrm{P}$ & $29.00 \mathrm{C}$ & $37.11 \mathrm{AB}$ & $35.91 \mathrm{~B}$ & $39.81 \mathrm{~A}$ \\
\hline & $\mathrm{NaHCO}_{3}-\mathrm{P}_{\mathrm{i}}$ & $72.14 \mathrm{C}$ & $83.43 \mathrm{~B}$ & $83.31 \mathrm{~B}$ & $88.42 \mathrm{~A}$ \\
\hline & $\mathrm{NaHCO}_{3}-\mathrm{P}_{\mathrm{o}}$ & $54.16 \mathrm{D}$ & $62.81 \mathrm{C}$ & $75.10 \mathrm{~B}$ & $80.33 \mathrm{~A}$ \\
\hline & $\mathrm{NaOH} \mathrm{I}-\mathrm{P}_{\mathrm{i}}$ & $17.37 \mathrm{~B}$ & $20.68 \mathrm{~A}$ & $18.19 \mathrm{AB}$ & $17.37 \mathrm{~B}$ \\
\hline & $\mathrm{NaOH} \mathrm{I-P}$ & $19.22 \mathrm{C}$ & $27.08 \mathrm{~B}$ & $29.09 \mathrm{AB}$ & $33.28 \mathrm{~A}$ \\
\hline & $\mathrm{HCl}-\mathrm{P}_{\mathrm{i}}$ & $159.50 \mathrm{~A}$ & $155.61 \mathrm{~A}$ & $158.39 \mathrm{~A}$ & $153.16 \mathrm{~A}$ \\
\hline & $\mathrm{NaOH}$ II-P & $16.66 \mathrm{~A}$ & $15.84 \mathrm{~A}$ & $16.23 \mathrm{~A}$ & $16.50 \mathrm{~A}$ \\
\hline & $\mathrm{NaOH}$ II- $\mathrm{P}_{\mathrm{o}}$ & $2.46 \mathrm{~B}$ & $3.73 \mathrm{~A}$ & $4.37 \mathrm{~A}$ & $2.81 \mathrm{~B}$ \\
\hline & Residual P & $70.46 \mathrm{~A}$ & $51.72 \mathrm{~B}$ & $50.88 \mathrm{~B}$ & $47.73 \mathrm{~B}$ \\
\hline Total & $\left.\mathrm{mg} \mathrm{kg}^{-1}\right)$ & $440.97 \mathrm{C}$ & $457.99 \mathrm{BC}$ & $471.48 \mathrm{AB}$ & $479.39 \mathrm{~A}$ \\
\hline
\end{tabular}

The means with the same letter in each row are not significant according to Duncan test at probability of $5 \%$.

${ }^{*} \mathrm{FYM}_{0}=0, \mathrm{FYM}_{1}=2.5, \mathrm{FYM}_{2}=5$ and $\mathrm{FYM}_{3}=7.5 \mathrm{~g} \mathrm{pot}^{-1}$ residual fraction by $22.73 \mathrm{mg} \mathrm{kg}^{-1}$ of control treatment. Therefore, the percentage of residual fraction decreased from 16 to $10 \%$ of total soil P. Organic matter and soil $\mathrm{pH}$ may enhance transformation of some residual $\mathrm{P}$ fraction into other $\mathrm{P}$ fractions (Fuentes et al., 2008). Reduction of residual $\mathrm{P}$ fraction was reported when compost was applied to soil (Lee et al., 2004).

Phosphorus transformations: Distribution of phosphorus (as percentage of total content) among its various fractions in calcareous sandy soil was influenced by FYM additions (Table 2 and Fig. 2). The FYM addition at the highest level increased percentage of some fractions such as $\mathrm{NH}_{4} \mathrm{Cl}-\mathrm{P}, \mathrm{NaHCO}_{3}-\mathrm{Pi}$, $\mathrm{NaHCO}_{3}-\mathrm{Po}$ and $\mathrm{NaOH}$ I-Po from 6.6, 16.4, 12.3 and $4.4 \%$ of total soil $\mathrm{P}$, respectively, at $\mathrm{FYM}_{0}$ treatment to $8.3,18.4,16.8$ and $6.9 \%$ of total soil $\mathrm{P}$, respectively. Application of FYM at FYM 1 level caused an increase in the percentage of $\mathrm{NaOH}$ I-Pi from 3.9 to $4.5 \%$, but application of FYM at $\mathrm{FYM}_{2}$ level resulted in an increase in the percentage of $\mathrm{NaOH}$ II-Po from 0.6 to $0.9 \%$. On the other hand, the addition of FYM caused a decrease in $\mathrm{HCl}-\mathrm{Pi}, \mathrm{NaOH}$ II-Pi and residual $\mathrm{P}$ fractions from 36.2, 3.8 and $16 \%$ of total soil $\mathrm{P}$ at $\mathrm{FYM}_{0}$, respectively, to $31.9,0.6$ and $10 \%$ of total soil $\mathrm{P}$, respectively at the highest level of FYM (Fig. 2). There were changes in the proportional distribution of $\mathrm{P}$ in calcareous sandy soil and $\mathrm{P}$ was redistributed among the various fractions during FYM fertilization. The observed decreased amounts of $\mathrm{HCl}-\mathrm{Pi}, \mathrm{NaOH}$ II-Pi and residual $\mathrm{P}$ fractions were redistributed on $\mathrm{NH}_{4} \mathrm{Cl}-\mathrm{P}$, $\mathrm{NaHCO}_{3}-\mathrm{Pi}, \mathrm{NaHCO}_{3}-\mathrm{Po}, \mathrm{NaOH}$ I-Pi, $\mathrm{NaOH}$ I-Po and $\mathrm{NaOH}$ II-Po fractions. 


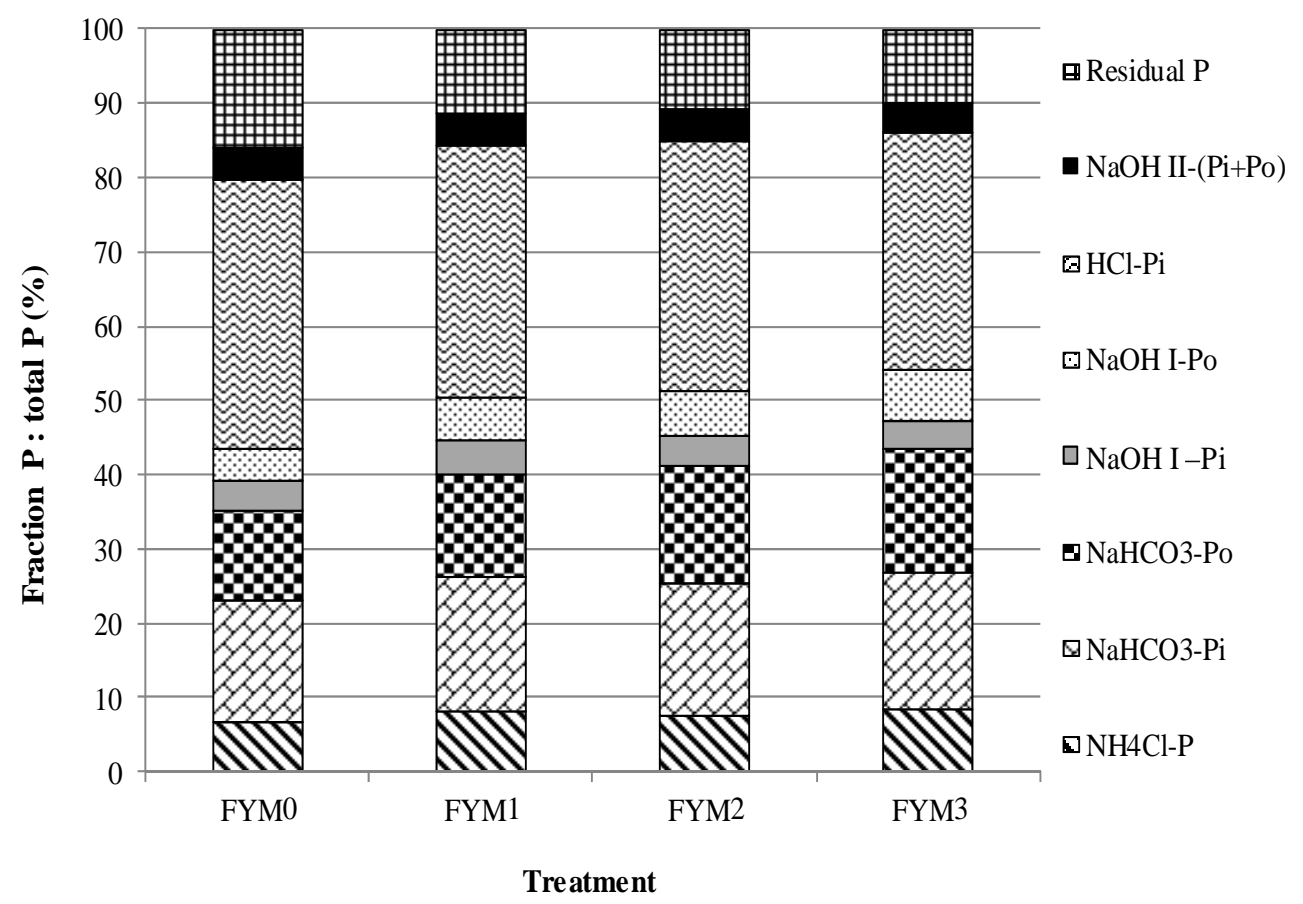

Figure 2. Effect of farmyard manure (FYM) on transformations of phosphorus fractions in calcareous sandy soil as a percentage of total phosphorus

Obviously, when FYM incubated with calcareous sandy soil, some amounts of moderately labile fraction ( $\mathrm{HCl}-$ $\mathrm{Pi})$ and stable fractions $(\mathrm{NaOH}$ II-Pi and residual $\mathrm{P})$ transformed to labile fractions $\left(\mathrm{NH}_{4} \mathrm{Cl}-\mathrm{P}, \mathrm{NaHCO}_{3}-\mathrm{Pi}\right.$, $\left.\mathrm{NaHCO}_{3}-\mathrm{Po}\right)$, some moderately labile fractions $(\mathrm{NaOH}$ $\mathrm{I}-\mathrm{Pi}, \mathrm{NaOH} \mathrm{I}-\mathrm{Po})$ and some stable fraction $(\mathrm{NaOH}$ IIPo). Biosolids application to soil dissolved HCl-P fraction and transformed to $\mathrm{NaHCO}_{3}-\mathrm{Pi}$ and $\mathrm{H}_{2} \mathrm{O}-\mathrm{P}$ fractions because soil $\mathrm{pH}$ may play role in transformation of HCl-P fraction to other fractions (Sui et al., 1999). Moreover, application of manure to soil caused phosphorus fractions to transform from Al-P and Ca-P into moderately labile Po and moderately resistant Po as well as from O-P to highly resistant Po (Yin and Liang, 2013). Phosphorus fractions of studied calcareous sandy soil influenced by FYM additions which were decreased in the order of $\mathrm{HCl}-\mathrm{Pi}>$ $\mathrm{NaHCO}_{3}-\mathrm{Pi}>\mathrm{NaHCO}_{3}-\mathrm{Po}>$ residual $\mathrm{P}>\mathrm{NH}_{4} \mathrm{Cl}-\mathrm{P}>$ $\mathrm{NaOH}$ I-Po $>\mathrm{NaOH}$ I-Pi $>\mathrm{NaOH}$ II-Pi $>\mathrm{NaOH}$ II-Po (Fig. 2). Another study showed that the concentrations of $\mathrm{Pi}$ fractions were as follows $\mathrm{HCl}-\mathrm{Pi}>\mathrm{NaOH}-\mathrm{P}>$ $\mathrm{NaHCO}_{3}-\mathrm{P}>$ resin-P in calcareous soils (Yang and Jacobsen, 1990).

\section{Elemental sulfur application}

Soil pH and available phosphorus: Adding elemental sulfur to calcareous sandy soil caused significant decrease in soil $\mathrm{pH}$ from 7.55 at control treatment $\left(\mathrm{S}_{0}\right)$ to 7.36 for the highest level of elemental sulfur $\left(\mathrm{S}_{3}\right)$.

Applications of elemental sulfur to calcareous sandy soil inoculated with Thiobacillus bacteria decreased availability of phosphorus as compared to $\mathrm{S}_{0}$ treatment (Table 3). Available phosphorus in calcareous sandy soil was decreased from $44.01 \mathrm{mg} \mathrm{kg}^{-1}$ at $\mathrm{S}_{0}$ treatment to $34.63 \mathrm{mg} \mathrm{kg}^{-1}$ at the highest level of elemental sulfur. But the addition of $S$ to this soil at $S_{1}$ level led to the insignificantly increased of available phosphorus. Elemental sulfur is widely used in most high-pH soils because it reduces soil $\mathrm{pH}$ and has a low price. Adding elemental sulfur at highest level to calcareous sandy soil caused a decrease in soil $\mathrm{pH}$. Accordingly, soil $\mathrm{pH}$ dropped by 0.19 unit compared to the control after ten weeks of incubation. Soil $\mathrm{pH}$ decreases gradually with increasing levels of elemental sulfur added to the calcareous sandy soil. Decline in soil $\mathrm{pH}$ due to sulfur oxidation by Thiobacillus sp. bacteria produce sulfuric acid. The $\mathrm{pH}$ of calcareous sandy soil showed reduction from 8.48 to 7.88 with application of elemental sulfur after 64 days of incubation (Soaud et al., 2011). Oxidization of elemental sulfur in soil by microorganisms and chemical reactions led to a decrease in soil $\mathrm{pH}$ because of sulfuric acid production (Tisdale et al., 1997). Applications of elemental sulfur at the highest level to calcareous sandy soil inoculated with Thiobacillus bacteria decreased available phosphorus compared to the control. Since the amount of the shortage of available phosphorus was about 9.36 $\mathrm{mg} \mathrm{kg}{ }^{-1}$ in comparison with the control treatment. 
Reduction of the phosphorus availability concentration in this experiment with increasing the elemental sulfur levels except for the $S_{1}$ treatment of sulfur as a slight increase in the phosphorus availability. The use of sulfur in the calcareous sandy soil causes a decrease in the availability of phosphorus because of the low $\mathrm{pH}$ caused by the addition of sulfur, which leads to the solubility of calcium carbonate thus increasing calcium ions, which react with phosphorus, composed insoluble compounds. In some calcareous soils the available phosphorus decreased from 334.4 to $28.6 \mathrm{mg} \mathrm{kg}^{-1}$ at 128 days after incubation by application of $\mathrm{P}$ combined with elemental sulfur and sulfur-oxidizing bacteria (Soaud et al., 2011). The addition of sulfur at level 60 $\mathrm{kg} \mathrm{ha}^{-1}$ led to the decrease of phosphorus availability from 8.12 to $6.82 \mathrm{~kg} \mathrm{ha}^{-1}$, while the addition of sulfur at level $20 \mathrm{~kg} \mathrm{ha}^{-1}$ led to the increase of phosphorus availability from 8.12 to $9.35 \mathrm{~kg} \mathrm{ha}^{-1}$ compared to the control (Dhage et al., 2014). Elemental sulfur addition to calcareous soil caused a decrease in available Phosphorus due to dissolved calcium carbonate by $\mathrm{H}_{2} \mathrm{SO}_{4}$ produced from elemental sulfur oxidation resulting in an increase in soluble calcium, which reacts with phosphate forming insoluble calcium phosphate in this soil (Cifuentes and Lindemann, 1993). Availability of phosphorus decreased in soils as level of gypsum application increased because of reaction between soluble $\mathrm{Ca}^{2+}$ ions from gypsum and P (Mishra et al., 2003).

\section{Phosphorus fractions}

Labile fractions: The obtained results also showed a significant decrease in $\mathrm{NH}_{4} \mathrm{Cl}-\mathrm{P}$ fraction with applying elemental sulfur compared to $\mathrm{S}_{0}$ treatment (Table 3 ). Applications of elemental sulfur to calcareous sandy soil at level $\mathrm{S}_{3}$ caused a decrease in $\mathrm{NH}_{4} \mathrm{Cl}-\mathrm{P}$ fraction from 39.52 to $33.86 \mathrm{mg} \mathrm{kg} \mathrm{kg}^{-1}$. Elemental sulfur incubation with the calcareous sandy soil also resulted in non-significant decreases in $\mathrm{NaHCO}_{3}$-Pi fraction up to $\mathrm{S}_{2}$ level. However, non-significant increase in this fraction occurred by using $\mathrm{S}_{3}$ level (Table 3). $\mathrm{NaHCO}_{3}$ $\mathrm{Pi}$ fraction increased from $81.72 \mathrm{mg} \mathrm{kg}^{-1}$ at $\mathrm{S}_{0}$ treatment to $85.26 \mathrm{mg} \mathrm{kg}^{-1}$ at the highest level of elemental sulfur. Non-significant increases were also recorded in $\mathrm{NaHCO}_{3}$-Po fraction at $\mathrm{S}_{1}$ and $\mathrm{S}_{2}$ levels as compared to $\mathrm{S}_{0}$ treatment. However, no significant decrease in the $\mathrm{NaHCO}_{3}$-Po fraction was found at $\mathrm{S}_{3}$ level. In the present study, elemental sulfur applied as an amendment to the calcareous sandy soil was decreased gradually $\mathrm{NH}_{4} \mathrm{Cl}-\mathrm{P}$ fraction, where the percentage of this fraction decreased from 8.5 to $7.3 \%$ of total soil P. Release of free calcium ions to soil solution due to lowering soil $\mathrm{pH}$ and dissolving $\mathrm{CaCO}_{3}$ as result of elemental sulfur additions caused reduction in $\mathrm{NH}_{4} \mathrm{Cl}-\mathrm{P}$ fraction (Cifuentes and Lindemann, 1993). Previously, concentration of labile $\mathrm{P}$ decreased after 2 to 13 months of sulfur application (Ye et al., 2010). Elemental sulfur incubation with the calcareous sandy soil also has no much effect on the $\mathrm{NaHCO}_{3}-\mathrm{Pi}$ and $\mathrm{NaHCO}_{3}-\mathrm{Po}$ fractions. Values of $\mathrm{P}$ fraction associated with $\mathrm{Al}$ and Fe decreased steadily after sulfur applications (Ye et al., 2010).

Moderately labile fractions: Adding elemental sulfur to calcareous sandy soil showed insignificant decrease in $\mathrm{NaOH}$ I-Pi fraction (Table 3). While, significant increases in $\mathrm{NaOH}$ I-Po were found at $S_{1}$ and $S_{2}$ treatments, but, $S_{3}$ treatment did not show significant increases. Applied elemental sulfur to soil at $S_{1}$ treatment was found to increase $\mathrm{NaOH}$ I-Po fraction from 23.19 to $30.78 \mathrm{mg} \mathrm{kg}^{-1}$. The results illustrated significant decrease in $\mathrm{HCl}-\mathrm{Pi}$ fraction with application of elemental sulfur. $\mathrm{HCl}-\mathrm{Pi}$ fraction reduced from 169.86 to $139.94 \mathrm{mg} \mathrm{kg}^{-1}$ with elemental sulfur addition at $\mathrm{S}_{3}$ level to this soil. In the present study, when addition of $\mathrm{S}$ to this soil led to increase decrescent of $\mathrm{NaOH}$ I-Po fraction. After applying elemental sulfur to soil at $\mathrm{S}_{1}$ treatment, $\mathrm{NaOH}$ I-Po fraction percentage increased from 5.0 to $6.6 \%$ of total P. Ye et al. (2010) found that the amended soil by sulfur did not influence $\mathrm{P}$ concentrations in humic-fulvic acid $\mathrm{P}$ or alter its proportion to total $\mathrm{P}$. The HCl-P fraction shows a rapid reduction when amended by elemental sulfur, whereas this fraction reduced from 36.7 to $30.3 \%$ of total $\mathrm{P}$ with elemental sulfur addition at $\mathrm{S}_{3}$ level. In other words, it was affected by soil amended with elemental sulfur (differences of $29.2 \mathrm{mg} \mathrm{kg}^{-1}$ ). The $\mathrm{HCl}-\mathrm{P}$ fraction constituted the largest proportion of the total $\mathrm{P}$ in this soil.

Stable fractions: Elemental sulfur at levels of $S_{1}$ and $S_{2}$ exhibited non-significant changes in $\mathrm{NaOH}$ II-Pi fraction of this soil, while applying $\mathrm{S}_{3}$ level did not increase this fraction (Table 3). Moreover, elemental sulfur additions caused significant increment in $\mathrm{NaOH}$ II-Po fraction at $\mathrm{S}_{1}$ level (Table 3). Elemental sulfur application at $\mathrm{S}_{1}$ level led to increase in $\mathrm{NaOH}$ II-Po fraction from 3.10 to $4.73 \mathrm{mg} \mathrm{kg}^{-1}$. Residual $\mathrm{P}$ fraction of this soil showed significant increases due to application of elemental sulfur (Table 3). Elemental sulfur applied at the highest level was found to increase residual $\mathrm{P}$ fraction from 42.57 to $74.64 \mathrm{mg}$. The $\mathrm{NaOH}$ II-Po fraction tended to increase in soils with elemental sulfur application at $S_{1}$, where the percentage increases from 0.7 to $1.0 \%$ of total $\mathrm{P}$. but the addition of $\mathrm{S}$ at levels $S_{2}$ and $S_{3}$ caused reduced in this fraction. $\mathrm{NaOH}$ II-Po fraction is considered the least proportion of total phosphorus in this soil. $\mathrm{P}$ concentration in the residual fraction increased after elemental sulfur additions to this soil. Elemental sulfur applied at the highest level was found to increase the proportion of residual $\mathrm{P}$ fraction 
from 9.2 to $16.2 \%$ of total P. However, the residual $\mathrm{P}$ was influenced in soils fertilized with elemental sulfur (differences of $32.07 \mathrm{mg} \mathrm{P} \mathrm{kg}^{-1}$ ). However, Ye et al. (2010) reported that sulfur applications to soil did not alter $\mathrm{P}$ concentrations of residual fraction or its contribution to the total P.

Phosphorus transformations: Phosphorus distribution as percentage of total content was influenced by elemental sulfur (Fig. 3). Since under incubation treatment $\mathrm{S}_{3}$ increased $\mathrm{NaHCO}_{3}-\mathrm{Pi}, \mathrm{NaHCO}_{3}-\mathrm{Po}, \mathrm{NaOH}$
I-Po, $\mathrm{NaOH}$ II-Pi, $\mathrm{NaOH}$ II-Po and residual $\mathrm{P}$ fraction from 17.6, 14.6, 5.0, 3.5, 0.7 and $9.2 \%$ of total soil $\mathrm{P}$, respectively, for $S_{0}$ to $18.5,15.5,6.6,3.8,1.0$ and 16.2 $\%$ of total soil $\mathrm{P}$, respectively. Increases of most previous fractions were slight; except for the residual fraction which was high. Elemental sulfur application to this soil decreased $\mathrm{NH}_{4} \mathrm{Cl}-\mathrm{P}, \mathrm{NaOH}$ I-Pi and $\mathrm{HCl}-\mathrm{Pi}$ fractions from $8.5,4.1$ and $36.7 \%$ of total soil $\mathrm{P}$, respectively, to $7.3,3.9$ and $30.3 \%$ of total soil $\mathrm{P}$, respectively.

Table 3. Mean effects of elemental sulfur addition on soil pH, the amount of available, fractions and total phosphorous in calcareous sandy soil (values are averages of three replications)

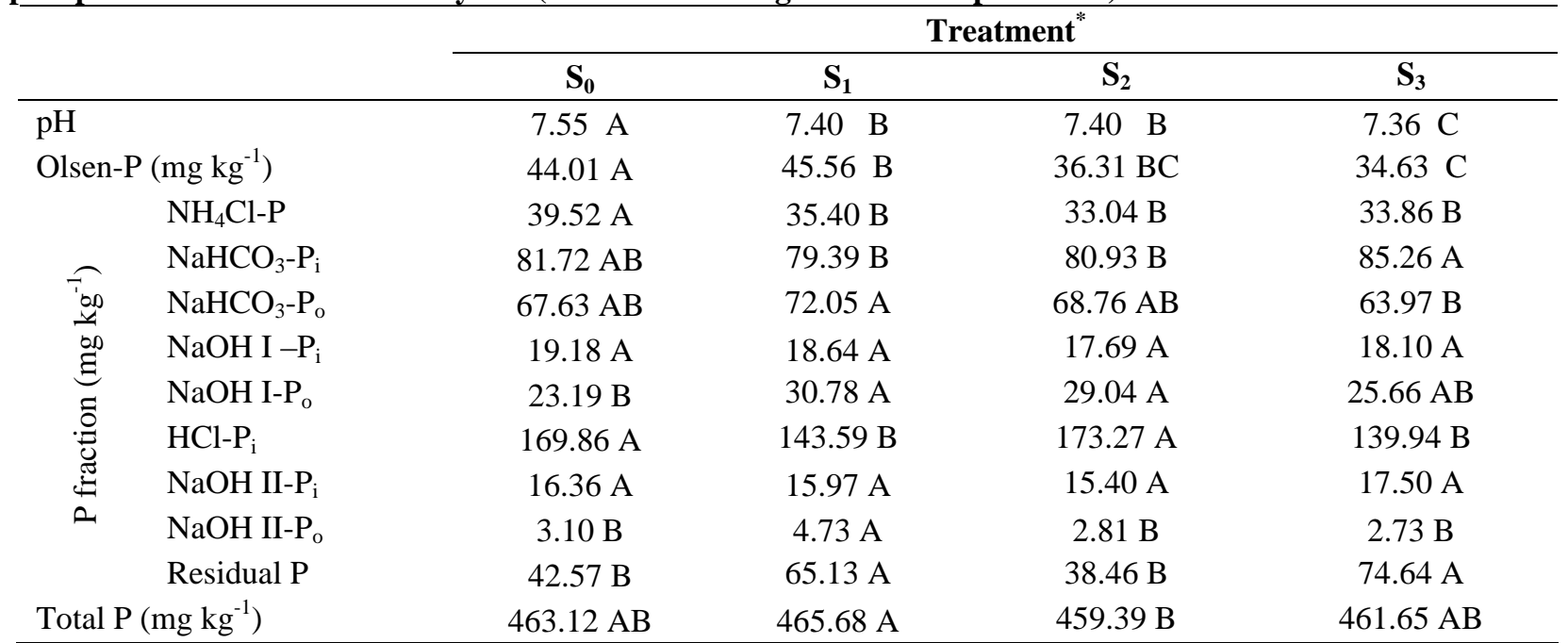

The means with the same letter in each row are not significant according to Duncan test at probability of 5\%.

${ }^{*} \mathrm{~S}_{0}=0, \mathrm{~S}_{1}=0.1, \mathrm{~S}_{2}=0.2$ and $\mathrm{S}_{3}=0.3 \mathrm{~g} \mathrm{pot}^{-1}$

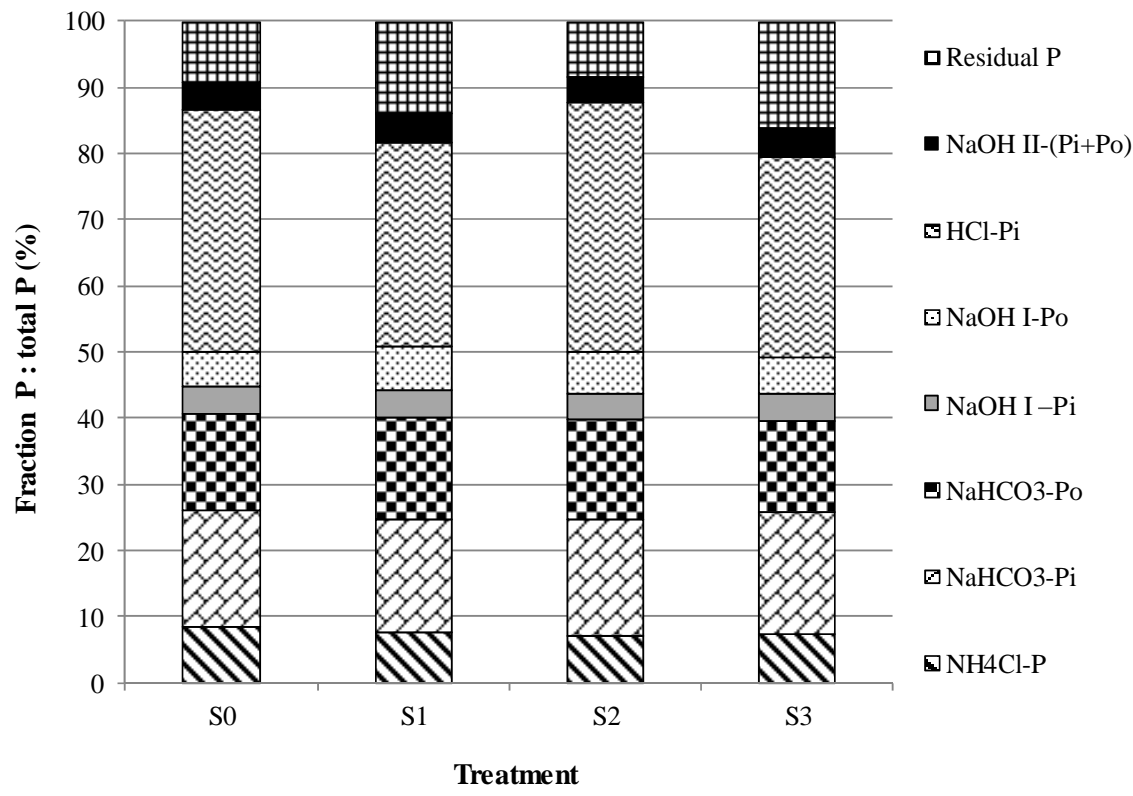

Figure 3. Effect of elemental sulfur (S) on transformations of phosphorus fractions of calcareous sandy soil as a percentage of total phosphorus 
Therefore, reduced $\mathrm{P}$ amounts of $\mathrm{NH}_{4} \mathrm{Cl}-\mathrm{P}, \mathrm{NaOH} \mathrm{I}-\mathrm{Pi}$ and $\mathrm{HCl}-\mathrm{Pi}$ fractions were redistributed and transformed to $\mathrm{NaHCO}_{3}-\mathrm{Pi}, \mathrm{NaHCO}_{3}-\mathrm{Po}, \mathrm{NaOH}$ I-Po, $\mathrm{NaOH}$ II-Pi $\mathrm{NaOH}$ II-Po and residual $\mathrm{P}$ fractions. Phosphorus fractions of calcareous sandy soil decreased in the order of $\mathrm{HCl}-\mathrm{Pi}>\mathrm{NaHCO}_{3}-\mathrm{Pi}>\mathrm{NaHCO}_{3}-\mathrm{Po}>$ residual $\mathrm{P}>$ $\mathrm{NH}_{4} \mathrm{Cl}-\mathrm{P}>\mathrm{NaOH}$ I-Po $>\mathrm{NaOH}$ I-Pi $>\mathrm{NaOH}$ II-Pi $>$ $\mathrm{NaOH}$ II-Po as a result of the elemental sulfur application (Fig. 3).

\section{Interaction effects of elemental sulfur and farmyard manure}

Soil pH, available and total phosphorus: The combined application of elemental sulfur with farmyard manure decreased soil $\mathrm{pH}$ from 7.54 for $\mathrm{S}_{0} \mathrm{FYM}_{0}$ to 7.35 at highest levels of sulfur and farmyard manure. Also, applications of elemental sulfur with farmyard manure showed significant increases in available Phosphorus of this soil at $\mathrm{S}_{1} \mathrm{FYM}_{1}$ from 42.95 to 52.70 $\mathrm{mg} \mathrm{kg}^{-1}$, while a significant decrease in available soil Phosphorus occurred at $\mathrm{S}_{2} \mathrm{FYM}_{1}$ (Table 4). Reduced phosphorus availability in calcareous soil might be attributed due to increase calcium ion in soil solution, due to decrease soil $\mathrm{pH}$, that precipitates Phosphorus as octacalcium phosphate. On the other hand, the combined application of elemental sulfur with farmyard manure increased significantly total $\mathrm{P}$ of calcareous sandy soil (Table 4). Applying a combination of FYM and elemental sulfur to calcareous sandy soil caused a drop of soil $\mathrm{pH}$ compared to the control. Reduction in soil $\mathrm{pH}$ was happened by 0.19 unit in comparison with the control treatment. The lowest value of $\mathrm{pH}$ in this soil observed at the highest levels of sulfur and farmyard manure. Interaction effect of elemental sulfur and cattle manure applications decreased $\mathrm{pH}$ of calcareous soil from 7.79 to 7.44 (Karimi et al. 2012). In the present study, the available phosphorus raised at the additions of mixing FYM and elemental sulfur at level $\mathrm{S}_{1} \mathrm{FYM}_{1}$ compared to the control. Such treatment has increased about $9.75 \mathrm{mg} \mathrm{kg}^{-1}$ compared to the control. The highest values of available phosphorus were observed at $\mathrm{S}_{1} \mathrm{FYM}_{1}, \mathrm{~S}_{1} \mathrm{FYM}_{2}$ and $\mathrm{S}_{1} \mathrm{FYM}_{3}$. In contrast the lowest concentrations of available phosphorus were observed at $\mathrm{S}_{2} \mathrm{FYM}_{1}$ and $\mathrm{S}_{3} \mathrm{FYM}_{2}$. Reduced phosphorus availability in calcareous soil might be attributed to increasing calcium ions in soil solution, due to decreasing soil $\mathrm{pH}$ that precipitates phosphorous as octacalcium phosphate.

Phosphorus fractions: Additions of elemental sulfur at $\mathrm{S}_{3}$ with $\mathrm{FYM}$ at $\mathrm{FYM}_{3}$ level caused a significant increase in the $\mathrm{NH}_{4} \mathrm{Cl}-\mathrm{P}$ fraction of this soil from 32.89 to $41.16 \mathrm{mg} \mathrm{kg}^{-1}$ (Table 4). The combined application of elemental sulfur with farmyard manure at their highest levels also showed significant increase in $\mathrm{NaHCO}_{3}-\mathrm{Pi}$ fraction of this soil from 61.36 to $91.55 \mathrm{mg}$ $\mathrm{kg}^{-1}$. Moreover, this exhibited a significant increase in $\mathrm{NaHCO}_{3}-\mathrm{Po}$ fraction. The addition of FYM and $\mathrm{S}$ together to this soil raised a $\mathrm{NaHCO}_{3}$-Po fraction from $58.59 \mathrm{mg} \mathrm{kg}^{-1}$ to $93.60 \mathrm{mg} \mathrm{kg}^{-1}$ at $\mathrm{S}_{1} \mathrm{FYM}_{3}$. Enhancing the $\mathrm{NH}_{4} \mathrm{Cl}-\mathrm{P}$ fraction was observed when farmyard manure applied combined with elemental sulfur at $\mathrm{S}_{3} \mathrm{FYM}_{3}$. The lowest value of the $\mathrm{NH}_{4} \mathrm{Cl}-\mathrm{P}$ fraction was noticed at $\mathrm{S}_{2} \mathrm{FYM}_{2}$, where the value of the $\mathrm{NH}_{4} \mathrm{Cl}-\mathrm{P}$ fraction was $32.61 \mathrm{mg} \mathrm{kg}^{-1}$. The highest value of the $\mathrm{NH}_{4} \mathrm{Cl}$-P fraction was observed at $\mathrm{S}_{3} \mathrm{FYM}_{3}$. The applied farmyard manure with elemental sulfur increased the percentage of this fraction from 7.3 to $8.3 \%$ at the $\mathrm{S}_{3} \mathrm{FYM}_{3}$ of the total $\mathrm{P}$, while at $\mathrm{S}_{1} \mathrm{FYM}_{1}$ the percentage of this fraction increased from 7.3 to $8.8 \%$ of the total $\mathrm{P}$, which represents little changes in the percentage of this fraction. Most treatments combined application of elemental sulfur with farmyard manure led to gradually increase in $\mathrm{NaHCO}_{3}-\mathrm{Pi}$ and $\mathrm{NaHCO}_{3}$-Po fractions. The percentage of $\mathrm{NaHCO}_{3}-\mathrm{Pi}$ and $\mathrm{NaHCO}_{3}-\mathrm{Po}$ fractions increased, however, the highest percentage of $\mathrm{NaHCO}_{3}$ Pi fraction noticed at $\mathrm{S}_{2} \mathrm{FYM}_{2}, \mathrm{~S}_{2} \mathrm{FYM}_{3}, \mathrm{~S}_{3} \mathrm{FYM}_{1}$, and $\mathrm{S}_{3} \mathrm{FYM}_{3}$ treatments. Moreover, the application of $\mathrm{S}$ and FMY together to this soil increases the percentage of $\mathrm{NaHCO}_{3}$-Po fraction from 13.1 to $19.4 \%$ of total $\mathrm{P}$ in soil over incubation period at $\mathrm{S}_{1} \mathrm{FYM}_{3}$, but the highest values were observed at $\mathrm{S}_{1} \mathrm{FYM}_{3}$ and $\mathrm{S}_{3} \mathrm{FYM}_{2}$. However, additions of elemental sulfur with FYM caused insignificant decreases in $\mathrm{NaOH}$ I-Pi fraction. On the other hand, additions of S with FYM caused a significant increase in $\mathrm{NaOH}$ I-Po fraction of the calcareous sandy soil. Adding $S$ at a level of $S_{1}$ with FYM at a level of $\mathrm{FYM}_{3}$ increased this fraction from 20.82 to $39.92 \mathrm{mg} \mathrm{kg}^{-1}$. Significant reduction in $\mathrm{HCl}-\mathrm{Pi}$ fraction from 172.00 to $133.65 \mathrm{mg} \mathrm{kg}^{-1}$ was found due to application of elemental sulfur with farmyard manure at their highest levels in calcareous sandy soil (Table 4). These were no effects of elemental sulfur with farmyard manure on $\mathrm{NaOH}$ II-Pi fraction of this soil (Table 4), while, the interaction effect of S and FYM application was significant for $\mathrm{NaOH}$ II-Po fraction. Sulfur treatment at a level of $\mathrm{S}_{1}$ with $\mathrm{FYM}$ at level $\mathrm{FYM}_{1}$ increased $\mathrm{NaOH}$ II-Po fraction from 0.73 to $6.63 \mathrm{mg}$ $\mathrm{kg}^{-1}$. Significant decrease in residual $\mathrm{P}$ fraction was observed because of application of elemental sulfur with farmyard manure in this soil (Table 4). Additions of elemental sulfur and FYM caused minor changes of $\mathrm{NaOH}$ I-Pi fraction compared to unamended soils. However, the changes of $\mathrm{NaOH}$ I-Po fraction were positive significant. The highest concentration of this fraction was founded at $\mathrm{S}_{1} \mathrm{FYM}_{3}$ accounted about $8.3 \%$ of total $\mathrm{P}$ in this soil. In general the concentrations of 
$\mathrm{HCl}-\mathrm{Pi}$ fraction tended to decrease with adding farmyard

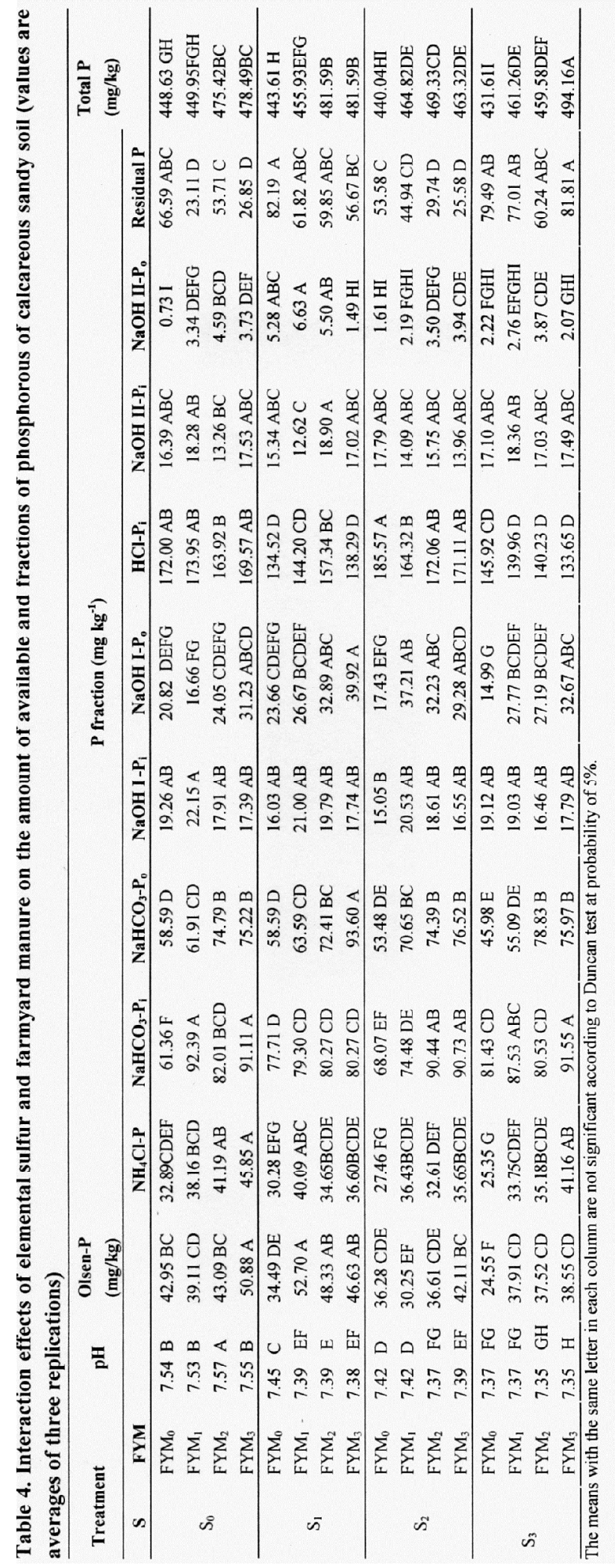




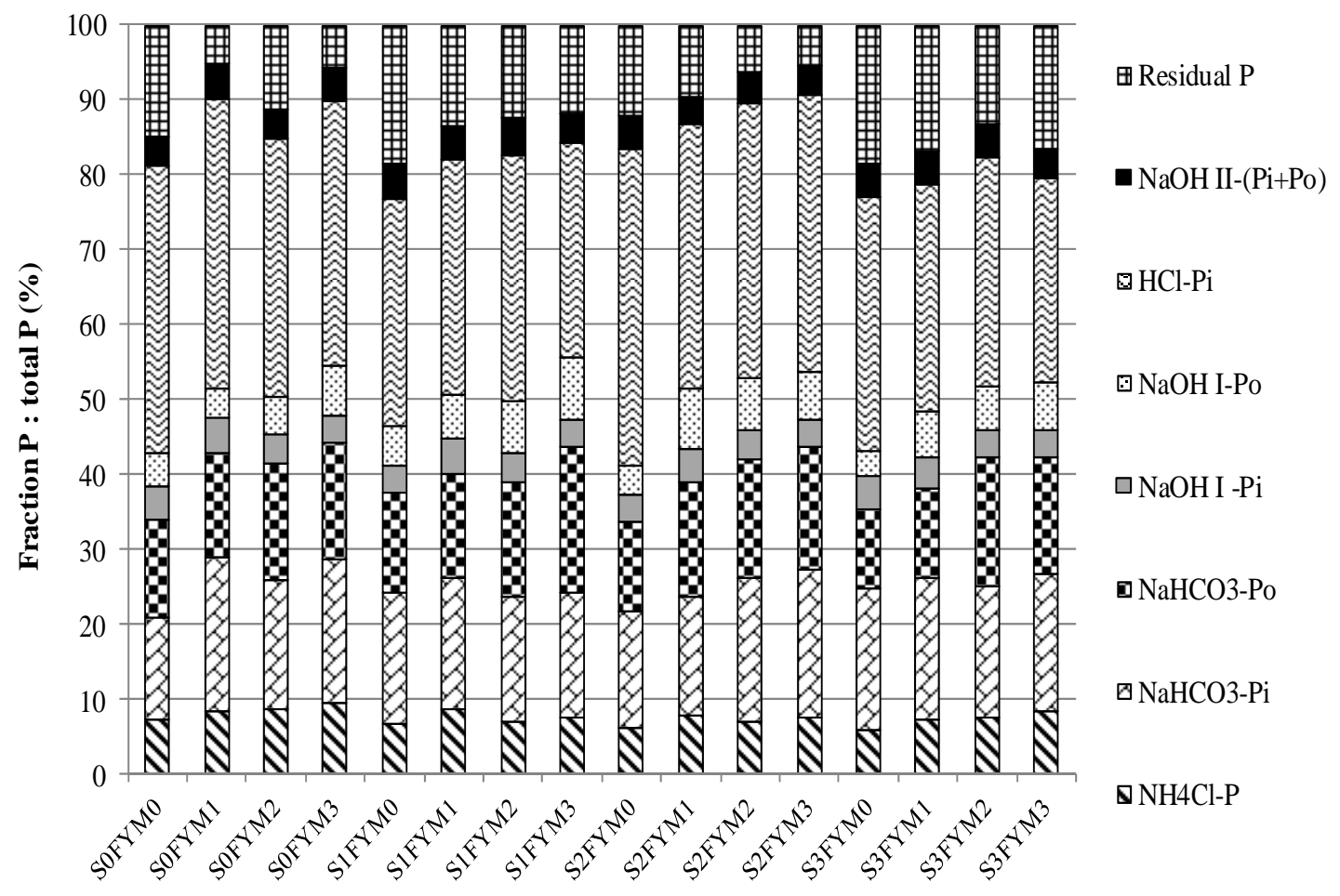

Treatment

Figure 4. Interaction effects of elemental sulfur and farmyard manure on transformations of phosphorus fractions of calcareous sandy soil as a percentage of total phosphorus

manure and elemental sulfur together to calcareous sandy soil and the proportions of $\mathrm{P}$ associated with the $\mathrm{HCl}-\mathrm{Pi}$ fraction decrease from $38.3 \%\left(\mathrm{~S}_{3} \mathrm{FYM}_{3}\right)$ to 27.0 $\%$ (control) of total $\mathrm{P}$. The concentration of residual $\mathrm{P}$ fraction reduced from $66.59 \mathrm{mg} \mathrm{kg}^{-1}$ at control to 25.58 $\mathrm{mg} \mathrm{kg}^{-1}$ for $\mathrm{S}_{2} \mathrm{FYM}_{3}$. But, at the highest level of sulfur with levels of farmyard manure caused an insignificant increase of residual $\mathrm{P}$ fraction, where increased residual $\mathrm{P}$ from 66.59 to $81.81 \mathrm{mg} \mathrm{kg}^{-1}$. The $\mathrm{NaOH}$ II-Po fraction tended to increase in calcareous sandy soil fertilized via farmyard manure combined with sulfur. Results indicated that, the application of FYM and $\mathrm{S}$ together decreases percentage of the residual-P fraction from 14.8 to $5.5 \%$ of total $\mathrm{P}$ at $\mathrm{S}_{2} \mathrm{FYM}_{3}$ treatment compared to the control. In contrast the additions of FYM with $S$ at highest levels caused the increase of residual-P fraction. The highest value of residual-P fraction was observed at $\mathrm{S}_{3} \mathrm{FYM}_{3}$, while the lowest value of this fraction noticed at $\mathrm{S}_{2} \mathrm{FYM}_{3}$.

Phosphorus transformations: Additions of elemental sulfur, at high level and farmyard manure at the highest level, to calcareous sandy soil increased $\mathrm{NH}_{4} \mathrm{Cl}-\mathrm{P}$, $\mathrm{NaHCO}_{3}-\mathrm{Pi}, \mathrm{NaHCO}_{3}-\mathrm{Po}, \mathrm{NaOH}$ I-Po, NaOH II-Po and residual fractions from 7.3, 13.7, 13.1, 4.6, 0.2 and 14.6 $\%$ of total soil P, respectively, to $8.3,18.5,15.4,6.6,0.4$ and $16.6 \%$ of total soil $\mathrm{P}$, respectively, on the expense of decreasing $\mathrm{NaOH}$ I-Pi, HCl-Pi and $\mathrm{NaOH}$ II-Pi fractions from 4.3, 38.3 and $3.7 \%$ of total soil $\mathrm{P}$, respectively, to $3.6,27.0$ and $3.5 \%$ of total soil $\mathrm{P}$, respectively (Fig. 4). Therefore, decrease in $\mathrm{P}$ of $\mathrm{NaOH}$ $\mathrm{I}-\mathrm{Pi}, \mathrm{HCl}-\mathrm{Pi}$ and $\mathrm{NaOH}$ II-Pi fractions were redistributed and transformed to $\mathrm{NH} 4 \mathrm{Cl}-\mathrm{P}, \mathrm{NaHCO}-\mathrm{Pi}$, NaHCO3-Po, NaOH I-Po, NaOH II-Po and residual fractions due to addition of elemental sulfur with farmyard manure.

\section{CONCLUSION}

Converting the phosphate ions produced from phosphate fertilizers to insoluble phosphate reduces the availability of soil phosphorus. Adding farmyard manure with elemental sulfur is considered to be important help in the progress of phosphorus availability in calcareous sandy soil, which is one of management and reclamation methods of this soil. This in turn leads to improve production efficiency of the soil. Since the applications of farmyard manure to the sandy calcareous soil converts the non labile fractions to labile and moderately labile fractions, we can recommend that adding farmyard manure to calcareous sandy soil as well as adding elemental sulfur at low levels combined with FYM. 


\section{REFERENCES}

Al-Oud, S.S. 2011. Improving phosphorus availability from phosphate rock in calcareous soils by amending with: organic acid, sulfur, and/or organic manure. Ozean J. Applied Sci. 4:227-235.

Badawy, F.H., M.M.M. Ahmed, H.M. El-Rewainy, and M.M.A. Ali. 2011. Response of wheat grown on sandy calcareous soils to organic manures and sulfur application. Egypt. J. Agric. Res. 89: 785-807.

Bahl, G.S., and G.S. Toor. 2002. Influence of poultry manure on phosphorus availability and the standard phosphate requirement of crop estimated from quantity-intensity relationships in different soils. Bioresource Technol. 85: 317-322.

Bowman, R.A. 1989. A sequential extraction procedure with concentrated sulfuric acid and dilute base for soil organic phosphorus. Soil Sci. Soc. Am. J. 53:362-366.

Brady, N.C., and R.R. Weil 1999. The Nature and Properties of Soils. Twelve Ed. Prentice-Hall International, Inc., Upper Saddle River, NJ., USA.

Chen, C.R., L.M. Condron, M.R. Davis, and R.R. Sherlock. 2000. Effects of afforestation on phosphorus dynamics and biological properties in a New Zealand grassland soil. Plant soil 220: 151-163.

Cifuentes, F.R., and W.C. Lindemann. 1993. Organic matter stimulation of elemental sulfur oxidation in a calcareous soil. Soil Sci. Soc. Am. J. 57: 727-731.

Delgado, A. and J. Torrent. 2000. Phosphorus forms and desorption patterns in heavily fertilized calcareous and limed acidic soils. Soil Sci. Soc. Am. J. 64:2031-2037.

Dhage, S.J., V.D. Patil, and A.L. Dhamak. 2014. Effect of phosphorus and sulphur levels on yield, fractions of phosphorus and sulphur and nitrate reductage activity of soil after harvest of soybean. An Asian J. Soil Sci. 9: 289-293.

Frossard, E., J.W.B. Stewart and R.J.St. Arnaud. 1989. Distribution and mobility of phosphorus in grassland and forest soils of Saskatchewan. Cand. J. Soil Sci. 69: 401416.

Fuentes B., M. de la Luz Mora, N.S. Bolan, and R. Naidu. 2008. Assessment of phosphorus bioavailability from organic wastes in soil. Developments in Soil Science, Chemical Bioavailability Terrestrial Environ. 32: 363-411.

Halajnia, A., G.H. Haghnia, A. Fotovat and R. Khorasani. 2009. Phosphorus fractions in calcareous soils amended with P fertilizer and cattle manure. Geoderma 150: 209213.

Havlin, J.L., J.D. Beaton, S.L. Tisdal, and W.L. Nelson. 1999. Soil Fertility and Fertilizers. An Introduction to Nutrient Management. 6th ed. Prentic Hall, New Jersy, USA.

Hedley, M.J., J.W.B. Stewart, and B.S. Chauhan. 1982. Changes in inorganic and organic soil phosphorus fractions induced by cultivation practices and by laboratory incubations. Soil Sci. Soc. Am. J. 46: 970-976.
Hopkins, B.G., and J.W. Ellsworth. 2005. Phosphorus availability with alkaline/ calcareous soil. Western Nutrient Management Conference. Salt Lake City, UT, USA; Vol. 6. p. 88-93.

Hosseinpur, A.R., Sh. Kiani, M. Halvaei. 2012. Impact of municipal compost on soil phosphorus availability and mineral phosphorus fractions in some calcareous soils. Environ. Earth Sci. 67: 91-96.

Iyamuremye, F., and R.P. Dick. 1996. Organic amendments and phosphorus sorption by soils. Adv. Agron. 56: 139185.

Iyamuremye, F., R.P. Dick, and J. Baham. 1996. Organic amendments and phosphorus dynamics: II. Distribution of soil phosphorus fractions. Soil Sci. 161: 436-443.

Jackson, M.L. 1973. Soil chemical analysis. Prentice-Hall, Inc., Englewood Cliffs. N.J. New Delhi.

Jalali, M. and F. Ranjbar. 2010. Aging effects on phosphorus transformation rate and fractionation in some calcareous soils. Geoderma 155: 101-106.

Kalembasa, S. and B. Kuziemska. 2007. Sequential analysis of phosphorus compounds of soil fertilized with waste organic materials. Polish J. Soil Sci. XL/2:165-172.

Karimi, F., M.A. Bahmanyar, and M. Shahabi. 2012. Investigation the effects of sulfur and cattle manure application on macronutrient availability in calcareous soil and accumulation in leaf and seed of canola. European Journal of Experim. Biol. 2: 836-842.

Kayser A., K. Wenger, A. Keller, W. Attinger, H.R. Felix, S.K. Gupta, and R. Schulin. 2000. Enhancement of phytoextraction of $\mathrm{Zn}, \mathrm{Cd}$, and $\mathrm{Cu}$ from calcareous soil: the use of NTA and sulphur amendments. Environ. Sci. Technol. 34: 1778-1783.

Leytem, A.B., and R.L. Mikkelsen. 2005. The nature of phosphorus in calcareous soils. Better Crops 89: 11-13.

Mishra, A., S.D. Sharma, and G.H. Khan. 2003. Improvement in physical and chemical properties of sodic soil by 3,6 and 9 years old plantation of Eucalyptus tereticornis: Biorejuvenation of sodic soil. Forest Ecology Manage. 184: 115-124.

Modaihsh, A.S., W.A. Al-Mustafa, and A.I. Metwally. 1989. Effect of elemental sulphur on chemical changes and nutrient availability in calcareous soils. Plant Soil 116: 95101.

Niederberger, J., B. Todt, A. Boča, R. Nitschke, M. Kohler, P. Kühn, and J. Bauhus. 2015. Use of near-infrared spectroscopy to assess phosphorus fractions of different plant availability in forest soils. Biogeosciences 12:34153428 .

Ojo, A.O., M.T. Adetunji, K.A. Okeleye, and C.O. Adejuyigbe. 2014. Changes in phosphorus fractions in manure and phosphorus fertilizer amended soil of southwestern Nigeria. Inter. J. Plant Soil Sci. 3: 71-84.

Olsen, S.R., C.V. Cole, F.S. Watanabe, and L.A. Dean. 1954. Estimation of available phosphorus in soils by extraction with sodium bicarbonate. Circular/United States Department of Agriculture (no. 939). 
Qian, P., and J.J. Schoenau. 2000. Fractionation of P in soil as influenced by a single addition of liquid swine manure. Cand. J. Soil Sci. 80: 561-566.

Scherer, H.W. and S.P. Sharma. 2002. Phosphorus fractions and phosphorus delivery potential of a luvisol derived from loess amended with organic materials. Biology Fertility Soils 35: 414-419.

Seidel H., J. Ondruschka, P. Morgenstern, U. Stottmeister. 1998. Bioleaching of heavy metals from contaminated aquatic sediments using indigenous sulphur-oxidizing bacteria: a feasibility study. Water Sci. Technol. 37:387394.

Sims, J.T., and B.G. Ellis. 1983. Adsorption and availability of phosphorus following the application of limestone to an acid, aluminous soil. Soil Sci. Soc. Am. J. 47:888-893.

Soaud, A.A., F.H. Al Darwish, M.E. Saleh, K.A. El-Tarabily, M. Sofian-Azirun, M.M. Rahman. 2011. Effects of elemental sulfur, phosphorus, micronutrients and Paracoccus versutus on nutrient availability of calcareous soils. Aust. J. Crop Sci. 5: 554-561.

Steel, R.G.D., and J.H. Torrie. 1982. Principles and procedures of statistics a biometrical approach. Mc Graw Hill Book Company, New York. USA.

Sui, Y., M.L. Thompson and C. Shang. 1999. Fractionation of phosphorus in a Mollisol Amended with biosolids. Soil Sci. Soc. Am. J. 63: 1174-1180.
Tisdale, S.L., W.L. Nelson, J.D. Beaton, and J.L. Havlin. 1997. Soil fertility and Fertilizers. 5th Ed. Prentice-Hall. of India. New Delhi.

Vance, C.P., C. Uhde-Stone and D.L. Allan. 2003. Phosphorus acquisition and use: critical adaptations by plants for securing a nonrenewable resource. New Phytologist 157 : 423-447.

Verma, S., S.K. Subehia and S.P. Sharma. 2005. Phosphorus fractions in an acid soil continuously fertilized with mineral and organic fertilizers. Biology Fertility Soils 41, 4, 295-300.

Verma, S.L. 2013. Effect of compost on soil phosphorus availability [Ph.D. Thesis]. School of Agriculture, Food and Wine, Waite Research Institute, the University of Adelaide, Adelaide, Australia.

Yang, J.E. and J.S. Jacobsen. 1990. Soil inorganic phosphorus fractions and their uptake relationships in calcareous soils. Soil Sci. Soc. Am. J. 54:1666-1669.

Ye, R., A.L. Wright, J.M. McCray, K.R. Reddy, and L. Young. 2010. Sulfur-induced changes in phosphorus distribution in Everglades Agricultural Area soils. Nutrient Cycling in Agroecosystems 87:127-135.

Yin, Y. and C.H. Liang. 2013. Transformation of phosphorus fractions in paddy soil amended with pig manure. J. Soil Sci. Plant Nutr. 13: 809-818. 


\section{الملخص العربي}

صلاحية وتحو لات الفوسفور في التربة الجيرية الرملية المتأثرة بإضافة السماد البلدى و الكبريت العنصري ابو العيون ابو زيد امين

المستخلص بواسطة بيكربونــات الــصوديوم و الفوسـفور

العضوى المستخلص بو اسطة بيكربونــات الــصوديوم و

الفوسـفور المعـدنى المستختلص بواســـة هيدروكسيد

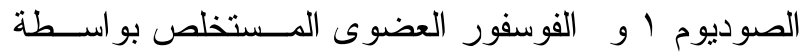

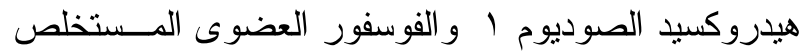

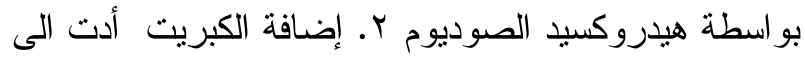
تحول صور الفوسفور المستخلص بواسطة كلوريد الامونيوم ، الفوسفور المعدنى المسـتخلص بواســة هيدروكسيد

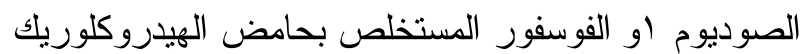

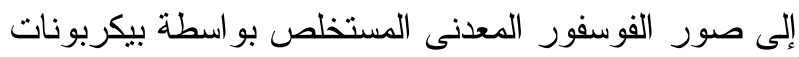

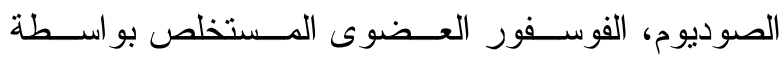

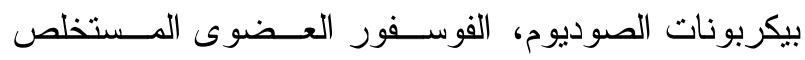

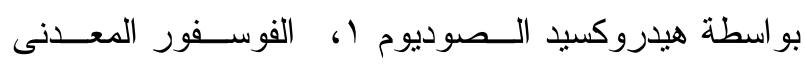
المستخلص بو اسطة هيدروكسيد الصوديوم Y ، ، والفوسـفور

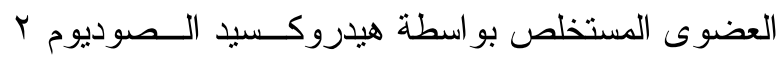
و الفوسفور المتبقى. نوصى بإضافة السماد البلدى إلى التربة

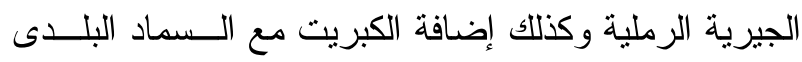
لتحسين خصائص التربة.
أجريت تجربة تحضين لدر اسة تــأثير الــسماد البـــدى

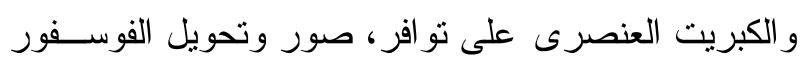

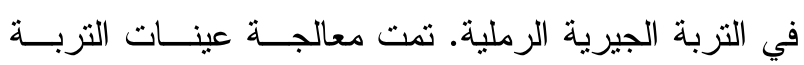

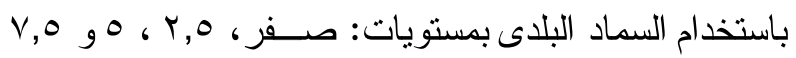

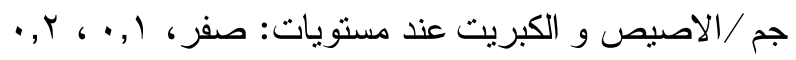
و r, • جم / الاصيص. تم تحضين التربة لمدة عشرة أسابيع

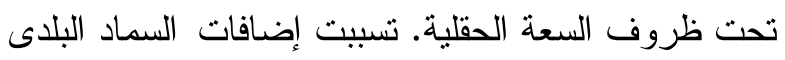
في حدوث زيادات معنوية في كمية الفوسفور الميسر مـن

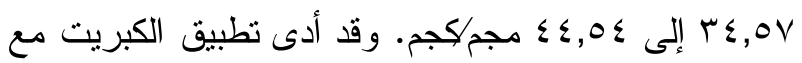

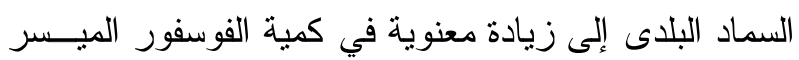
لهذه التربة عند المسنوى الاول من السماد البلدى و الكبريت من 9, 90

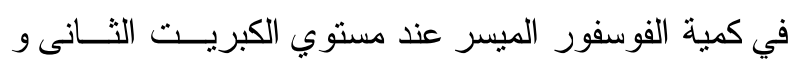

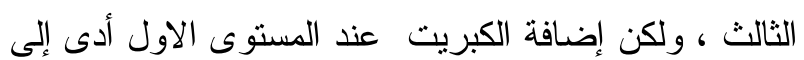

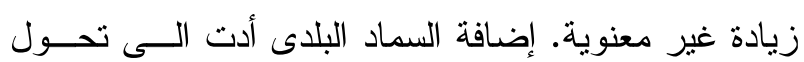
صور الفوسفور المستخلص بحــامض الهيــدروكلوريك و الفوسـفور المعـدنى المستخلص بو اسـطـة هيدروكسيد

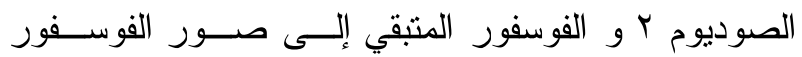
المستخلص بواسطة كلوريد الامونيوم و الفوسفور المعـدنى المونى 